\title{
ICT and Knowledge Management for Organizational Competitiveness: Understanding Policy and Practices
}

\author{
Miftahus Sa'adah \\ Department of Islamic Education Management \\ Universitas Islam Negeri Sunan Kalijaga \\ Yogyakarta, Indonesia \\ miefsa@yahoo.co.id
}

\author{
Siti Nur Hidayah \\ Department of Islamic Education Management \\ Universitas Islam Negeri Sunan Kalijaga \\ Yogyakarta, Indonesia \\ siti.hidayah@uin-suka.ac.id
}

\begin{abstract}
Globalization has inevitably forced organization including higher education institution to improve its competitive advantage. Recently, the notion of knowledge management has been gaining wide acceptance toward organizational enhancement. It includes the use of technology to support knowledge creation, storage, transfer and implementation. However, the utilization of advanced technology, for some organizations, likewise conveys some problems. This article investigates the Centre of Information Technology and Database (PTIPD) as a unit responsible for data management and the use of ICT as enabler for knowledge creation and dissemination among academia at Sunan Kalijaga State Islamic University Yogyakarta. This article studies the university's policy in terms of technology implementation and its budgeting as well as its member's perception on the technology implemented. A number of organization's members participated in interviews of this qualitative study. The results of this study found that the use of ICT and the role played by PTIPD remain mediocre and should be improved to accommodate actual knowledge management system. Eventually, this article recommended the improvement of ICT implementation at Sunan Kalijaga State Islamic University. Furthermore, this study will be enlightening for researchers and practitioners of knowledge management particularly in relation to the use of ICT as knowledge enabler.
\end{abstract}

Keywords-ICT, knowledge management, higher education, management information system.

\section{INTRODUCTION}

Globalization has conveyed remarkable changes in every aspect of life including higher education institution. Rigid competition requires organization to rigorously increase its capacity as well as enhance its knowledge assets. Moreover, the ability to smartly manage knowledge reside within an organization is also considered as a critical factor to survive in the global era. Higher education institution, as the center of knowledge development responsible for knowledge creation and dissemination, is expected to play role to accommodate the global demand which can be achieved by advancing its competitive advantages. To address this, effective knowledge management system implemented through Information and Communication Technology (ICT) effectiveness is inevitable. Information and communication terchnologies help to facilitate knowledge creation and acquisition, knowledge conversion, dissemination, and utilization [1].
The formulation of the ICT and knowledge management in higher education institutions should contribute to the improvement of teaching-learning processes. The use of ICT by the member of the university, i.e. academic staff, nonacademic staff, and students should also accelerate the flow of information as well as encourage the creation, development and dissemination of knowledge. However, the heterogeneity of the users' competence in employing the ICT should also be addressed as it influences the effectiveness of the system. The ease of use, data accessibility and the user-friendly system are significant to ensure the optimum operation of the ICT system which further enhance the institution competitiveness.

The ICT and knowledge management systems within higher education institutions, nonetheless, necessitate complete support from the policy makers as it demands considerable amount of fund. The awareness of those in authority that these two components are remarkably critical needs to be ensured. Their encouragement on this area will definitely enhance the institution's preparedness to the global challenges.

There has been numerous body of literature discussing the implementation of knowledge management such as that conducted by [2] who studied the implementation of knowledge management in higher education institutions. He concluded that knowledge management within higher education institutions can be implemented through the academic digital dashboard knowledge management system. This signifies mutual cooperation among groups of knowledge worker, i.e. researchers and lecturers, led by a chief knowledge officer (CKO) to actively participate in establishing the foundation of knowledge and further formulating the strategy, model and the architecture of knowledge management operational. Meanwhile, [3] investigated the role of knowledge management in library context. She argued that library should understand the concept of knowledge management as well as provide knowledge management facilities to offer excellent services for the customers. On the other hand, [4] examined the implementation of knowledge management in the library of Curup State Islamic College and identified three forms of knowledge management implementation, i.e., Islamic classical book digitalization, knowledge sharing through book review, and staff knowledge sharing.

Among enablers for knowldege management, strategy and leadership argued to be the most influential factor to the 
success of KM implementation [5]. Another researches suggested that top management position in supporting the impementation of KM writen by [6], as they have strategic role in securing financial and organizational culture to build $\mathrm{KM}$ infrastructure.

In terms of the role of ICT in knowledge management and the enablers for KM, numerous studies have also emerged, such as those conducted by [7],[8],[9],[10],[11], [6], [12], [13], [14], and [15]. The more recent studies examined the ICT's influence on knowledge management, innovation and colearning by applying an economical approach [16] and the significance of new technologies implementation within KM in order to achieve collaborative work [1], and [17].

However, research on policy and practice of the ICT and knowledge management for institution competitiveness is still limited. To address this, the purpose of this research is to study the university's policy in terms of ICT implementation as enabler for knowledge creation and dissemination among academia at Sunan Kalijaga State Islamic University Yogyakarta, a prominent Islamic University in Indonesia striving to achieve the World-Class Research University rank and its budgeting as well as its member's experiences on the technology implemented. It also investigates the center of information technology and data bases (PTIPD) as a unit responsible for the data management within the university.

\section{METHOD}

This study uses a qualitative research method examining the ICT function as knowledge management enabler to improve organization competitiveness in Sunan Kalijaga State Islamic University, a higher education institution with a vision of achieving World Class Research University in the field of Islamic studies. The data were collected through documentation, observation, and in depth interview. The preparation of the research was conducted to determine the focus of the study, research framework, data collection methods, and the subject involved in the study.

The research framework is then elaborated so that it corresponds to the instrument that depict all aspects being studied. The instruments were elaborated in the form of guidelines for data collection methods, which contained interview guide, observation, and document study.

The process of this qualitative study, involving data collection, processing, analysis and result display were caried out for approximately four months. This periode of time and stages were intended to canvass the practice and experiences of the stakeholders in dealing with ICT to store, share, and use of knowledge in the university. Detailed data about the policy and implementation for the development of ICT as enabler for knowledge management were then evaluated as a basis to determine the role and direction of the development of ICT to build a competitive organizational performance.

Observation was conducted to examine the daily practices of ICT usage, accessibility, as well as services provided regarding the ICT. On the other hand, interview was conducted using interview guide. The interviewees were selected based on purposive technique by considering their power, expertise, and understanding on the subject. The interviews was conducted with twenty four respondents to gain rich data about the role of ICT to support the practice of managing knowledge in an Islamic Higher education institution. Two vice rectors, i.e. vice rector for general administration, planning and finance; and vice rector for academic affairs and organizational development; and two top managers at the Center for Information Technology and Database were interviewed regarding the policy set by the university. On the other hand, the practice experienced in the use of ICT for knowledge management were gathered from students, lecturers, and nonacademic staff.

The validity of the data was tested with the degree of credibility, transferability, dependability, and conformability. Using triangulation technique, the level of trust of the information is checked through multilevel sources (participants involved in the interviews) as well as formal documents records. Furthermore, data analysis was conducted with Miles \& Huberman method involving three intertwined activities i.e. data reduction, data display, and conclusion or verivication.

\section{RESULT AND DISCUSSION}

\section{A. Strategic Position Of PTIPD}

State Islamic University Sunan Kalijaga Yogyakarta is one of the oldest Islamic higher institutions in Indonesia. Established in 1950s, the university is now starting to develop its organization to become a world class research university in the field of Islamic studies in 2038. In doing so, the university widely recognizes that in the era of knowledge economy, managing tacit knowledge as an asset is among the crucial matter to be addressed. In 2004, the Center for Computer and Information System was established by combining two previous body of Center for Computer Unit and Information System Unit. It is only in 2013, the center name and function were transformed into Center for Information Technology and Databases (PTIPD) in correspond to the development of State Islamic University achievement of wider mandate as a university [18]. This transformation were adopted as the need for assurance of both data processing and data management, as well as the critical demand for accurate and degenerative information display.

PTIPD is led by a chairman whose role is Chief of ITCs Officer opted by the Rector, under the coordination and responsibility of the Vice Rector for General Administration, Planning, and Finance. It main responsibility is to manage and develop the management of information system, applications and network maintenance and improvement, databases management, other technology development and network partnership [19].

Practically, PTIPD has developed three main objectives, they are: infrastructure and facility, service, and partnership. In regards to infrastructure facility, the center has provided intranet and internet access into almost $90 \%$ of all rooms in the campus compounds. It also developed the servers availability, from server tower form into the blade-shaped servers shelves since 2011, for better access performance. Another infrastructure developed by the center was the implementation 
of IP-based devices, including IP telephony, camera, and television. The IP telephony has also been able to connect to outside service providers like GSM and PSTN channels [18]

In terms of service automation, the center has developed numbers of information systems to support academic and management performances. The information system comprises academic matters, library, media, administrative, mailing, internet, as well as system for student payment which is integrated in cooperation with banks. Abiding connection and access, all members of staff and students in the university were provided with single account to connect to all services provided by PTIPD, and were given daily access quota. The center has also built wireless access in 150 points which cover internet access over $90 \%$ of campus areas. Furthermore, the center provided regular ICT trainings for students, Google corner to introduce Google services that can be benefited by all academic communities in the campus [18].

In terms of performance development, the center cooperated with International Business Machine (IBM), Google.inc, and Microsoft. In 2014, PTIPD has awarded Top National TESCA winner by a Telkom Smart Campus Award, after reviewing over 600 universities in Indonesia. The award considered ICT infrastructures, application, human resources as well as policy application.

\section{B. Policy for ICT development as Enabler for Knowledge Management}

The role of PTIPD is essential in enabling the university in its way to manage knowledge and information asset for organizational competitiveness. PTIPD as ICT center ought to develop and implement cyber services for academic community. Beside that, it develops and implement interaction canal for cyber workspaces, provide various medias for information sharing for all element of UIN Sunan Kalijaga community by developing understanding and awareness about the urgency and importance of information technology as well as improving people skills in the usage of information technology.

The center has developed a strategic planning namely Master Plan for Information Technology Development (RIPTI) since 2004 during the transition of the institution in becoming a university, as before become a university, UIN Sunan Kalijaga Yogyakarta was an institute (IAIN Sunan Kalijaga).

To support the university vision and mission to be internationally recognized, the center built a roadmap to make the university a cyber campus to come true. It planned that the ICT development should achieve both short and long term goals. By stressing the believe to build a digital culture among academic communities and elements in the campus, the stages of development aimed to be achieved by the center during the priode of 2014-2038 are formulated in the list below. Each goal would be achieved within three years period (19). The programs are as follows:
- Automation of the academic and administrative processes at the University

- Mobility application by implementing mobile working application model to support academic and administrative processes accros space and time

- Paper-free workplace model by ensuring that all documents and forms can be represented in electronic/digital form. This stage requires applicable rules and policies to support this peperless working model

- Seamless services to enable academic comunities to gain access for the data, transactions, and information through various medias and devices anytime at any places by developing cloud services

- Virtual workspaces to provide alternative media for collaborative work regardless the constrain of space and time by developing virtual applications

- The application of augmented reality technologies in the virtual workspaces to enhance users' experiences and support academic as well as managerial performance improvement

- Smart campus stage would be achieved by providing automatic resources needed by academic communities in the university by developing the decision support system application, and expert system application.

The smart campus achievement is planned to correspond with the achievement of the university as a world class university in Islamic studies by time and program. Presently, numbers of application have been automated and are ubiquitous. The above plan is also affirmed by vice rector for academic affairs and organizational development of UIN Sunan Kalijaga yogyakarta.

In terms of budgeting, the university sets a routine annual budget for PTIPD for the amount of 1.2 Billion Rupiahs in its annual Budget Plan. According to the vice rector for general administration, planning, and finance, in 2017, the university allocate extra budget for a very important IT infrastructure for data storage and maintenance by investing in DRC (Disaster Recovery Center) with the amount of budget reached four billion rupiahs. Top management and PTIPD managements believe that to optimise the role of ICT to support organizational performance. Nevertheless, one of the challenge faced by the center is the limitation of budget due to the status of the university as a state university which budget partly depend on the government with rigid rule of budgetary disbursement. Likewise, the vice rector for general administration stated that the budget allocated for e-journal disbursement provided by the library reached one billion annualy, to foster the development of knowledge among lecturers, students, and researchers in the university. This condition describe the attention of top management in 
knowledge management as an important trigering element for successful knowledge management [11], [6], and [12].

Responding ICTs problems experienced by PTIPD, the policy would be focused to improve infrastructure performance. Besides building the DRC, the policy would be focused on infrastructure development by inceasing the number of servers owned by university to overcome the problem of academic access during peak seasons such as in registration time when thousands of students access academic information system at the same time. Building one server for one application considered to be the best solution for the ease of access load.

On ther hand, data integration among different information systems at UIN Sunan Kalijaga Yogyakarta should be enhanced to optimise the data usage and sharing so that the academic communities in the campus could optimize their knowledge for organizational competitiveness. Involving the academic information system integration with repository at the library, with research, publication, as well as community service. Data integration is crucial, not only in providing knowledge, but also its usage in further knowledge development that is beneficial for the university. The picture about the policy regarding ICT and Knowledge Management development best described in the table 1 .

Table 1. Policy in ICT and KM Development of UIN Sunan Kalijaga Yogyakarta

\begin{tabular}{|c|c|c|}
\hline Category & Program & Activity/outcome \\
\hline $\begin{array}{l}\text { Top } \\
\text { Management }\end{array}$ & $\begin{array}{l}\text { - Training and } \\
\text { development } \\
\text { - Program to enhance } \\
\text { knowledge distribution } \\
\text { and sharing } \\
\text { - Compensation, } \\
\text { appraisal, and reward }\end{array}$ & $\begin{array}{l}\text { - Provide training to develop } \\
\text { human resources in the } \\
\text { implementation ICT in } \\
\text { service, teaching, and } \\
\text { learning process (but still } \\
\text { limited due to budget) } \\
\text { - Initiate programs to foster } \\
\text { publication, seminar, } \\
\text { workshops, and presentation } \\
\text { forums for lecturers and } \\
\text { researchers } \\
\text { - Providing compensation and } \\
\text { reward for knowledge } \\
\text { sharing through publications } \\
\text { and for knowledge } \\
\text { development } \\
\text { researches through }\end{array}$ \\
\hline & $\begin{array}{l}\text { - Cross exposure to } \\
\text { knowledge }\end{array}$ & $\begin{array}{l}\text { - Regular job rotation to } \\
\text { expose different knowledge } \\
\text { and experience among staff }\end{array}$ \\
\hline
\end{tabular}

Table 1, Cont.

\begin{tabular}{|c|c|c|}
\hline Infrastructure & $\begin{array}{l}\text { - Infrastructure } \\
\text { development } \\
\text { - Optimising } \\
\text { knowledgeable } \\
\text { employee } \\
\\
\text { - Data integration }\end{array}$ & $\begin{array}{l}\text { - Increasing the number of } \\
\text { servers } \\
\text { - Planning to invest in DRC } \\
\text { (Disaster Recovery Center) } \\
\text { - Limited number of human } \\
\text { resources knowledgeable } \\
\text { in ICT matters requires the } \\
\text { university to consider } \\
\text { optimization of human } \\
\text { resource by employing } \\
\text { students skilled on ICT } \\
\text { - Need to develop } \\
\text { information system to } \\
\text { integrate data among other } \\
\text { related systems such as } \\
\text { academic information } \\
\text { system with research, } \\
\text { publication, and } \\
\text { community services }\end{array}$ \\
\hline $\begin{array}{l}\text { Organizational } \\
\text { Culture }\end{array}$ & $\begin{array}{l}\text { - Collaboration and } \\
\text { Group interactivity } \\
\text { - Providing service and } \\
\text { initiating Google } \\
\text { corner } \\
\text { - Knowledge use and } \\
\text { share }\end{array}$ & $\begin{array}{l}\text { - Need to develop awareness of } \\
\text { collaboration among } \\
\text { stakeholders in the university } \\
\text { as well as group interactivity } \\
\text { - Facilitating any problems and } \\
\text { assistance to solve ICT } \\
\text { related problem and Google } \\
\text { service optimization for } \\
\text { education } \\
\text {-Enhancing knowledge share } \\
\text { and use among academic } \\
\text { community by optimizing } \\
\text { repository and library services } \\
\text { and subscribe for databases } \\
\text { accessible for academic } \\
\text { communities }\end{array}$ \\
\hline Budgeting & $\begin{array}{l}\text { - Annually planned } \\
\text { budget } \\
\\
\\
\\
\text { - Extra additional } \\
\text { budget }\end{array}$ & $\begin{array}{l}\text { The budget is set annually by } \\
\text { the university for operational } \\
\text { programs at ICT and } \\
\text { databases center } \\
\text { Allocated for very important } \\
\text { need for ICT development } \\
\text { and knowledge management } \\
\text { such as for the investment in } \\
\text { DRC }\end{array}$ \\
\hline
\end{tabular}

The above policy was partly formulated in the master plan and annual budget and activity planning, but partly was still in process of discussion by policy makers. 


\section{ICT and Knowledge management Practices}

According to twenty four respondents in this study, the practice regarding ICT as one of the enablers of Knowledge Management were varied. The writer categorize the practices into five matters, they are: practices regarding Information system, communication infrastructure, accessibility, knowledge usage and sharing through repository and website, and services provided by PTIPD.

Regarding information system, particularly that of Academic Information System (AIS), all respondets consider the system to be easy to use and access. The AIS is number one application used by the respondents compared to other information systems due to some reasons such as its function to gain updated information about registration, examining students presence in class so that they can measure their eligibility to conduct middle and final examination, filling the form for study planning per semester, as well as to input the data (student score, presence, or student feedback).

In addition, the existence of AIS believed to be very influential to support academic matters and make it easier for user to access since it is connected via internet, so everyone can have access to it ubiquitously. The respondent listed the advantages of AIS such as easy to access, flexible, developed overtime, can be accessed anytime and everywhere. Nevertheless, the challenges faced involving network and server limitation.

In terms of communication infrastructure, UIN Sunan Kalijaga Yogyakarta has a partnership with Google. inc in managing its institutional email. All members of the university are eligible for the email address, however, numbers of respondents from student element argued for not having the email yet due to the lack of information they received. Different from the AIS one, email usage considered to be less used. Most of the respondent showed that they barely use the institutional email due to both its difficulty in usage and lack of information about the email account. The difficulty of usage was particularly because the account does not use person's name but it uses employment identity number that comprises of very long number series. The number use for email account considered as impractical and difficult to remember, especially if it is used to communicate with other persons from outside the university.

In terms of website development, PTIPD facilitates each study programs to develop their own webpages. In fact, despite its outdated information most of the respondents were rarely visit the websites due to their traditional performances. In regard to new development of ICT, PTIPD need to develop social web technologies to become a key tool for information and $\mathrm{KM}$ within the university as well as a tool for competition and interaction with customers accross organizations as has been reviewed in [1]. New ICTs in terms of "semantic web" describe the evolution from document-based web into new paradigm of data and information that can be manipulated by computers. As outlined by [1] with appropriate training and education, new ICTs will assist the organization to acquire, store, and dissemintae knowledge.
Regarding access to the internet, 150 access point developed by the university (PTIPD) in the areas accross campus being argued to be not enough compared to total number of UIN Sunan Kaliajaga members, besides it dificult to access. Almost all respondents argue that the access for internet is limited to certain places only, even in certain rooms within campus, wifi access is often unreachable. Furthermore, "in peak hours, after 15 people logged in to the wifi, the other user would not be able to get in the wifi", said a respondent.

Pertaining to knowledge usage and shares among students, lecturers and staff members, in fact, the library has provided a repository, e-journal, and online services. Unfortunately, respondents said that they barely access to the library or its ejournal. Eventhough the library subscribe to certain databases, however very limited number of updated journal articles could be accessed. The case of sub unit websites/ portal was the same. Almost all respondents argues for not regularly access to the study program or faculty websites due to the outdated information. On the other hand, in relation to services provided by PTIPD, respondents pays good notes to the service. The staff at PTIPD were friendly and provide excellent services for their customers.

Implementing knowledge management by using ICT in Islamic Higher education still face many challenges. The respondents in this study listed the following problems that challenge KM implementation:

- $\quad$ Limited and inflexible usage of budget due to fixed rule in budgetary spending established by the government

- Lack of number of knowledgeable human resources to operate and develop ICT to maximize its role in managing knowledge in the university

- Low awareness level from the academic community in the campus on the importance of managing knowledge. Beside that, numbers of lecturers feel that they have knowledgeable enough that do not need to develop their knowledge by searching and using knowledge databases. This point affirms the point written in [20].

- Some of the academicians and non academic staff have limited skills in ICT usage, and rarely use it to develop their knowledge or services

The policy regarding ICT and Knowledge Management in UIN Sunan Kalijaga Yogyakarta were directed to support the road of the university to become an internationally recognized institution. Whereas, its practices remained fairly fine within the area being studied. Unfortunately, challenges shall always existed in maximizing the role of ICT in Knowledge management. The challenges were also typically found in other higher institutions in the same case as has been discussed by [15], [20], and [17].

\section{CONCLUSION}

To sum up, the role of ICT as the enabler for Knowledge management practices is crucial in supporting UIN Sunan 
Kalijaga Yogyakarta to become a world class university in Islamic studies. Strategic planning to the development of ICT established by Center for Information Technology and Databases (PTIPD) has been very feasible, reinforced by the policy and top management attention to the development of the center. On the other hand, the practice regarding ICT experienced by students, lecturers and administrative staff remain medium tend to fair regarding $\mathrm{Wi}-\mathrm{Fi}$ access availability, easy access to institutional email, as well as ejournal databases provided by university library which is lacking and outdated. Furthermore, the policy and practices of ICT faces numbers of challenges such as limited budget and inflexible use of budget due to rigid rule from the government, ICT skills lacking among users, as well as the lack of awareness among academicians to develop their knowledge using ICT and services provided by the university. The development of new ICTs would better foster the university to gain better performance as a world class university in Islamic studies.

\section{ACKNOWLEDGMENT}

The writers would like to thank to the Department of Islamic Education Management, UIN Sunan Kalijaga Yoggyakarta for all its support. To all the respondents and enumerators who participate in this study, we thank you very much.

\section{REFERENCES}

[1] Soto-Acosta P, Cegarra-Navarro J-G. New ICTs for Knowledge Management in Organizations. $\mathrm{J}$ Knowl Manag [Internet]. 2016;20(3):1-10. Available from: http://www.emeraldinsight.com/doi/abs/10.1108/JKM-02-20160057

[2] Mulyanto A, Pendahuluan A. Implementasi Knowledge Management. 2008;71-8.

[3] Pasaribu IM, Sos S. Implementasi Knowledge Management dan Analisis SWOT di Perpustakaan Perguruan Tinggi Dosen Universitas Sari Mutiara Indonesia Medan. 2012, pp.156-70.

[4] Rodin R, Lebong R. PENERAPAN KNOWLEDGE MANAGEMENT DI PERPUSTAKAAN ( Studi Kasus di Perpustakaan STAIN Curup ), 2013,pp.35-46.

[5] Ho C-T. The relationship between knowledge management enablers and performance. Ind Manag Data Syst. 2009;109(1):98117.

[6] Ritika E, Saini R. Model Development for Key Enablers in the Implementation of Knowledge Management. IUP J Knowl Manag [Internet]. 2013 [cited 2017 Apr 21];11(2):46-62. Available from: http://web.a.ebscohost.com.ezproxy.ugm.ac.id/ehost/pdfviewer/pdf viewer?vid=4\&sid=0ddbbbfd-ccb2-4cc9-ba576fe3fa6ab7e1\%40sessionmgr4007\&hid=4112

[7] Hendriks PHJ. Many rivers to cross: From ICT to knowledge management systems. J Inf Technol. 2001;16(2),pp.57-72.

[8] Majors I. ICT and Knowledge Management Models for Promotion of SME's Competitiveness. 2010;6(3).

[9] Aknovia Y. Aplikasi Model Knowledge Management Metrik Dalam Mengukur Peranan Ict Di Perguruan Tinggi Negeri ( Studi Kasus : Uin Suska Riau ). 2014;11(2),pp.243-50.
[10] Jeng DJ-F, Dunk N. Knowledge Management Enablers and Knowledge Creation in ERP System Success. Int J Electron Bus Manag [Internet]. 2013;11(1):49-59. Available from: http://search.proquest.com/docview/1353551844 ?accountid=35273 \%5Cnhttp://gx8zx6zq4j.search.serialssolutions.com/?ctx_ver=Z39. 88-2004\&ctx_enc=info:ofi/enc:UTF-

8\&rfr_id=info:sid/ProQ:abiglobal\&rft_val_fmt=info:ofi/fmt:kev:m tx:journal\&rft.genre=article\&rft.jt

[11] Fattahiyan S, Hoveida R, Siadat SA, Tallebi H. Study of relationship between knowledge management enablers and processes with organizational performance. Interdiscip J Contemp Res Bus [Internet]. 2012 [cited 2017 Apr 21];4:36-44. Available from: http://connection.ebscohost.com/c/articles/83518279/studyrelationship-between-knowledge-management-enablers-processesorganizational-performance

[12] Anantatmula VS, Kanungo S. Modeling enablers for successful KM implementation. In: Proceedings of the Annual Hawaii International Conference on System Sciences [Internet]. 2007 [cited 2017 Apr 21]. Available from: https://pdfs.semanticscholar.org/8606/80d6166e478125287c5f31dc b20c821b7860.pdf

[13] Kamhawi EM. Knowledge management fishbone: a standard framework of organizational enablers. J Knowl Manag [Internet]. 2012 Sep 7 [cited 2017 Apr 21];16(5):808-28. Available from: http://www.emeraldinsight.com/doi/10.1108/13673271211262826

[14] Theriou N, Maditinos D, Theriou G. Knowledge management enabler factors and firm performance: An empirical research of the Greek medium and large firms. Eur Res Stud J [Internet]. 2011 [cited 2017 Apr 21];14(2):97-134. Available from: http://abd.teikav.edu.gr/new_articles/030_knowledge.pdf

[15] Adekunle Okunoye, Helena Karsten. TUCS Publication Database: Where the Global Needs the Local: Variation in Enablers in the Knowledge Management Process [Internet]. Journal of Global Information Technology Management 5(3), 12-31, 2002. [cited 2017 Apr 21]. Available from: http://tucs.fi/publications/view/?pub_id=jOkKa02a

[16] García-Álvarez MT. Analysis of the effects of ICTs in knowledge management and innovation: The case of Zara Group. Comput Human Behav. 2015;51:994-1002.

[17] Duţă N, Martínez-Rivera O. Between Theory and Practice: The Importance of ICT in Higher Education as a Tool for Collaborative Learning. Procedia - Soc Behav Sci [Internet]. 2015;180(November 2014):1466-73. Available from: http://www.sciencedirect.com/science/article/pii/S1877042815016 407

[18] PTIPD UIN Sunan Kalijaga Yogyakarta. Service and Facility Profile of the Center for Information Technology and Databases. 2016. p. 1-40.

[19] Yogyakarta PUSK. Master Plan for Information Technology Development. 2014. p. 1-12.

[20] Prabowo H. Knowledge Management Di Perguruan Tinggi. Binus Bus Rev. 2010;1(2):407-15. 